UDC 678

\title{
Investigation of the effect of the amount of additives on the properties of adipic acid esters
}

\author{
Authors: \\ Aliya K. Mazitova, \\ Professor, Head of Applied and Natural Sciences Department, Ufa State Petroleum Technological University, \\ Ufa, Bashkortostan Republic, Russia, elenaasf@yandex.ru; \\ Irina N. Vikhareva, \\ Assistant, Applied and Natural Sciences Department, Ufa State Petroleum Technological University, \\ Ufa, Bashkortostan Republic, Russia, vikhir@yandex.ru; \\ Guliya K. Aminova, \\ Professor, Applied and Natural Sciences Department, Ufa State Petroleum Technological University, \\ Ufa, Bashkortostan Republic, Russia, aminovagk@inbox.ru; \\ Andrey A. Timofeev, \\ Associate Professor, Applied and Natural Sciences Department, Ufa State Petroleum Technological University, \\ Ufa, Bashkortostan Republic, Russia, tiandre@mail.ru; \\ Evgeniya A. Buylova, \\ Associate Professor, Applied and Natural Sciences Department, Ufa State Petroleum Technological University, \\ Ufa, Bashkortostan Republic, Russia, asunasf@mail.ru;

\section{Ramil Sh. Distanov,} \\ Senior lecturer, Applied and Natural Sciences Department, Ufa State Petroleum Technological University, \\ Ufa, Bashkortostan Republic, Russia, distanov_ramil1@mail.ru
}

\begin{abstract}
Polyvinylchloride (PVC) is the most frequently used polymer for obtaining a wide range of materials for various purposes. The main advantages of the polymer - excellent thermal and electrical insulation properties, high resistance to various aggressive substances, namely: acids, alkalis, various lubricants; lack of taste, smell; low water absorption (0.4-0.6\%). The possibility to obtain PVC-plasticates with different characteristics is provided by the introduction of various additives, the bulk of which are plasticizers. Plasticizers based on adipic acid esters give a number of valuable properties to PVC-based compositions.

However, the use of plasticizers affects the resistance of compounds to the combustion, therefore, the substances which eliminate this disadvantage are added in the polymer composition.

This paper presents the results of a study of the effect of the composition of mixed plasticizers (symmetric and asymmetric adipates of aliphatic alcohols and phosphate of oxypropylated phenol) on the flammability of PVC composition.

Primarily symmetric adipate of cyclic aliphatic alcohols and asymmetric adipate of aliphatic alcohols containing cycloalkyl radical have been derived. Then phosphate of oxypropylated phenol has been synthesized. Physical and chemical properties of the synthesized compounds were studied. Mixtures of plasticizers on the basis of the symmetric adipate of cyclic aliphatic alcohols and asymmetric adipate of aliphatic alcohols containing cycloalkyl radical with varying amounts of phosphate of oxypropylated phenol have been composed. The results of tests of PVC compositions containing the obtained mixtures of plasticizers for flammability are presented. Combustibility parameters of cable plasticate samples with the use of developed plasticizers correspond to state standard 5960-72 with changes 3-9. The best results were achieved with the use of asymmetrical adipate of aliphatic alcohols containing cycloalkyl radical and $4 \%$ by weight phosphate of oxypropylated phenol. It is shown that small amounts of phosphate oxypropylated phenol are able to reduce flammability, further addition of this plasticizer leads to a deterioration in performance. The developed formulations of PVC plastics are recommended for use in the production of polyvinylchloride cable sheaths.
\end{abstract}

Keywords: adipate of aliphatic alcohols, combustibility, PVC compounds, plasticizers of polyvinylchloride, phosphate of oxypropylated phenol.

For citation: Mazitova A.K., Vikhareva I.N., Aminova G.K., Timofeev A.A., Buylova E.A., Distanov R.Sh. Investigation of the effect of the amount of additives on the properties of adipic acid esters. Nanotehnologii v stroitel'stve = Nanotechnologies in Construction. 2019, Vol. 11, no. 4, pp. 437-446. DOI: 10.15828/2075-8545-2019-11-4-437-446. 

rel="dct:type" $>$ Investigation of the effect of the amount of additives on the properties of adipic acid esters $</$ span $>$ by $<$ a xmlns:cc="http://creativecommons. org/ns\#" href="Nanotehnologii v stroitel'stve = Nanotechnologies in Construction. 2019, Vol. 11, no. 4, pp. 437-446. DOI: 10.15828/2075-8545-2019-11-4-437446" property="cc:attributionName" rel="cc:attributionURL">Mazitova A.K., Vikhareva I.N., Aminova G.K., Timofeev A.A., Buylova E.A., Distanov R.Sh.</a > is licensed under a $<$ a rel="license" href="http://creativecommons.org/licenses/by/4.0/" $>$ Creative Commons Attribution 4.0 International License $</ a>.<$ br $/>$ Based on a work at <a xmlns:dct="http://purl.org/dc/terms/" href="http://nanobuild.ru/en_EN/nanobuild-4-2019/" rel="dct:source" $>$ http://nanobuild.ru/en_EN/nanobuild-4-2019/</a $>$. $<$ br $/>$ Permissions beyond the scope of this license may be available at $<$ a xmlns:cc="http://creativecommons.org/ns\#" href="vikhir@yandex.ru" rel="cc:morePermissions" $>$ vikhir@yandex.ru $</ a>$.

The paper has been received by editors: 27.05.2019.

The paper has been received by editors after peer-review: 22.06.2019.

The paper has been accepted for publication: 05.07.2019.

\title{
Исследование влияния количества добавок на свойства эфиров адипиновой кислоты
}

\author{
Авторы: \\ Мазитова Алия Карамовна, \\ профессор, зав. каф., ФГБОУ ВО «Уфимский государственный нефтяной технический университет», \\ г. Уфа, Республика Башкортостан, Россия, elenaasf@yandex.ru; \\ Вихарева Ирина Николаевна, \\ ассистент каф., ФГБОУ ВО «Уфимский государственный нефтяной технический университет», \\ г. Уфа, Республика Башкортостан, Россия, vikhir@yandex.ru; \\ Аминова Гулия Карамовна, \\ профессор каф., ФГБОУ ВО «Уфимский государственный нефтяной технический университет», \\ г. Уфа, Республика Башкортостан, Россия, aminovagk@inbox.ru; \\ Тимофеев Андрей Алексеевич, \\ доцент каф., ФГБОУ ВО «Уфимский государственный нефтяной технический университет», \\ г. Уфа, Республика Башкортостан, Россия, tiandre@mail.ru;

\section{Буйлова Евгения Андреевна,} \\ доцент каф., ФГБОУ ВО «Уфимский государственный нефтяной технический университет», \\ г. Уфа, Республика Башкортостан, Россия, evg-builova@yandex.ru;

\section{Дистанов Рамиль Шамильевич,} \\ старший преподаватель кафедры «Прикладные и естественнонаучные дисциплины», \\ ФГБОУ ВО «Уфимский государственный нефтяной технический университет», \\ г. Уфа, Республика Башкортостан, distanov_ramil1@mail.ru
}

Резюме: Поливинилхлорид (ПВХ) является наиболее часто используемым полимером для получения широкого ассортимента материалов различного назначения. Основные достоинства полимера - отличные тепло- и электроизоляционные свойства, высокая устойчивость к действию различных агрессивных веществ, а именно кислот, щелочей, различных смазок; отсутствие вкуса, запаха; низкое водопоглощение (0,4-0,6\%). Возможность получить ПВХ-пластикаты с различными характеристиками обеспечивается внесением различных добавок, основную часть которых составляют пластификаторы. Пластификаторы на основе эфиров адипиновой кислоты придают ряд ценных свойств композициям на основе ПВХ.

Однако использование пластификаторов ухудшает стойкость пластикатов к горению, поэтому в полимерные композиции добавляют вещества, которые позволяют устранить этот недостаток.

В данной работе приведены результаты исследования влияния состава смешанных пластификаторов (симметричных и несимметричных адипинатов алифатических спиртов и фосфата оксипропилированного фенола) на горючесть ПВХкомпозиции.

В первую очередь, получены симметричные адипинаты циклических алифатических спиртов и несимметричные адипинаты алифатических спиртов, содержащие циклоалкильный радикал. Затем синтезирован фосфат оксипропилированного 
фенола. Изучены физико-химические свойства синтезированных соединений. Составлены смеси пластификаторов на основе симметричных адипинатов циклических алифатических спиртов и несимметричных адипинатов алифатических спиртов, содержащих циклоалкильный радикал, с различными количествами фосфата оксипропилированного фенола. Представлены результаты испытаний ПВХ-композиций, содержащих полученные смеси пластификаторов, на горючесть. Показатели горючести образцов кабельного пластиката с применением разработанных пластификаторов соответствуют ГОСТ 5960-72 с изм. 3-9. Наилучшие результаты были достигнуты с применением несимметричных адипинатов алифатических спиртов, содержащих циклоалкильный радикал, и 4\% масс. фосфата оксипропилированного фенола. Показано, что именно небольшие количества фосфата оксипропилированного фенола способны обеспечить снижение горючести, дальнейшее добавление данного пластификатора приводит к ухудшению показателей. Разработанные рецептуры ПВХпластикатов рекомендуются для использования при получении поливинилхлоридных оболочек кабелей.

Ключевые слова: адипинат алифатических спиртов, горючесть, пластикат, пластификаторы поливинилхлорида, фосфат оксипропилированного фенола.

Для цитирования: Мазитова А.К., Вихарева И.Н., Аминова Г.К., Тимофеев А.А., Буйлова Е.А., Дистанов Р.Ш. Исследование влияния количества добавок на свойства эфиров адипиновой кислоты // Нанотехнологии в строительстве. - 2019. - Том 11, № 4. - C. 437-446. - DOI: 10.15828/2075-8545-2019-11-4-437-446.

\footnotetext{
Машиночитаемая информация о СС-лицензиях (HTML-код) в метаданных статьи

$<$ rel="license" href="http://creativecommons.org/licenses/by/4.0/"><img alt="Creative Commons License" style="border-width:0" src="https:/i.creativecommons.org/l/by/4.0/88x31.png" / ></a $><$ br / > span xmlns:dct="http://purl.org/dc/terms/" href="http://purl.org/dc/dcmitype/Text" property="dct:title" rel="dct:type" $>$ Investigation of the effect of the amount of additives on the properties of adipic acid esters $</$ span $>$ by $<$ a xmlns:cc="http://creativecommons. org/ns\#" href="Nanotehnologii v stroitel'stve = Nanotechnologies in Construction. 2019, Vol. 11, no. 4, pp. 437-446. DOI: 10.15828/2075-8545-2019-11-4-437446" property="cc:attributionName" rel="cc:attributionURL">Mazitova A.K., Vikhareva I.N., Aminova G.K., Timofeev A.A., Buylova E.A., Distanov R.Sh.</a > is licensed under a $<$ a rel="license" href="http://creativecommons.org/licenses/by/4.0/" $>$ Creative Commons Attribution 4.0 International License $</$ a $>$. $<$ br $/>$ Based on a work at <a xmlns:dct="http://purl.org/dc/terms/" href="http://nanobuild.ru/en_EN/nanobuild-4-2019/" rel="dct:source" >http://nanobuild.ru/en_EN/nanobuild-4-2019/</a $>$. $<$ br $/>$ Permissions beyond the scope of this license may be available at $<$ a xmlns:cc="http://creativecommons.org/ns\#" href="vikhir@yandex.ru" rel="cc:morePermissions" $>$ vikhir@yandex.ru $</ a>$.
}

Статья поступила в редакцию: 27.05.2019.

Статья поступила в редакцию после рецензирования: 22.06.2019.

Статья принята к публикации: 05.07.2019.

\section{INTRODUCTION}

$\mathrm{P}$ olyvinylchloride contains up to $56 \%$ chlorine, so it is not combustible in pure form. However, with the addition of plasticizers the combustibility of materials based on it increases, a dramatic change is observed when the content of additives is more than $25 \%$ [1-6].

It is known from the researches that low combustibility indices of polymeric materials are given by phosphoruscontaining compounds [7-13]. The most effective flame retardants are triarylphosphates. However, phosphorus-containing plasticizers are not widely used, as they adversely affect a number of physical and mechanical properties of the compositions: low-temperature flexibility, volatility, thermal stability and color stability; use of them also complicates the technology of processing of polymeric materials [14-17].

Adipic acid esters don't possess these disadvantages, they also give PVC materials stability at low temperatures, resistance to UV light, high resistance to migration to gasoline and oil [18-22].

Therefore, we have studied mixed plasticizers based on adipic acid esters with the addition of small amounts of aryl-containing phosphates.

\section{MAIN PART}

\section{Experimental part}

We have conducted research on the preparation of a mixture of adipate of aliphatic alcohols and small amount of phenoxypropylated phosphate with low flammability PVC compounds.

This paper describes methods for the synthesis, physico-chemical properties of symmetrical and asymmetrical adipate of aliphatic alcohols and phenoxypropylated phosphate, results of their testing as cable tracks. 
The method of obtaining symmetrical adipate of cyclic aliphatic alcohols

The production of symmetrical adipate is carried out in the presence of concentrated sulfuric acid (catalyst) in a solution of azeotrope waterpicker toluene, at reflux of the latter. The molar ratio taken for the reaction of alcohols and adipic acid is $2.2: 1$. The reaction is controlled by the amount of produced water, and acid number of ester. After cooling, the reaction mass is washed sequentially from the catalyst with a $5 \%$ solution of alkali and water to a neutral reaction. The resulting esters are dried over freshly calcined sodium sulfate and the solvent is distilled under vacuum. The yield of target products is $96-98 \%$.

The method of obtaining asymmetric adipate of cyclic and acyclic aliphatic alcohols

Asymmetric esters of adipic acid are obtained in two stages. At the first stage, under the conditions described above at the molar ratio acid: alcohol $=1: 1$, monoesters of acyclic alcohols are synthesized. Further, they are isolated with the use of $10 \%$ solution of sodium hydroxide with subsequent treatment with hydrochloric acid. At the second stage, the obtained monoesters under the same conditions react with cyclohexylcarbinol at the molar ratio acid: alcohol $=1: 1,2$. The outcome of asymmetric esters is not less than $96 \%$.

Physical and chemical parameters of the synthesized esters of adipic acid are shown in table 1.

The table shows that the structure of alcohol radicals in the obtained esters significantly affects the lowtemperature properties of esters. The replacement of two acyclic alkyl radical in the cyclic structure results is likely to receive more rigid and less flexible molecules. Replacement of alkyl groups of normal structure by branched allows obtaining adipic acid esters with a pour point below $-60^{\circ} \mathrm{C}$.

Phosphate of oxypropylated phenol was obtained in two stages. At first stage, oxypropylated phenol was syn- thesized. Then by means of esterification of it with adipic acid the final product was obtained.

\section{Methods of phenol oxypropylating}

$94.0 \mathrm{~g}(1 \mathrm{~mol})$ of phenol and $1.6 \mathrm{~g}(1.0 \%$ by weight of the total load) of sodium hydroxide catalyst are loaded in the reactor equipped with a stirrer, refrigerator, thermometer, lowered into the liquid, and a drop funnel. Mixing and heating of the flask is launched and remove air by nitrogen blowing. Upon reaching the desired temperature, $58.0 \mathrm{~g}$ $(1 \mathrm{~mol})$ of propylene oxide is gradually introduced from the drop funnel. After stopping the feed, the reaction mixture is stirred for 1.5 hours without changing the temperature, then it is cooled. To remove the catalyst, the mixture is neutralized with the calculated amount of sulfuric acid and filtered. After drying with anhydrous sodium sulfate it is distilled under vacuum. Outcome is 1-phenoxy-2-propanol $147.1 \mathrm{~g}(96.8 \%), \mathrm{d}^{2}{ }_{04}=1,063 \mathrm{~g} / \mathrm{ml}, \mathrm{n}^{20}{ }_{\mathrm{D}}=1,525$, m.w. 152 , the degree of oxypropylating -1 .

\section{Method of esterification of phosphoric acid}

$456 \mathrm{~g}$ (3.1 mol) of 1-phenoxy-2-propanol is added to a mixture of $153.3 \mathrm{~g}(1.0 \mathrm{~mol})$ phosphorus oxychloride and $1.0 \mathrm{~g}(0.01 \mathrm{~mol})$ anhydrous magnesium chloride, heated to $45^{\circ} \mathrm{C}$ for three hours. The reaction mixture is stirred and heated to $80^{\circ} \mathrm{C} / 30 \mathrm{~mm} \mathrm{Hg}$ within eight hours. $25 \mathrm{~g}(0.27 \mathrm{~mol})$ of epichlorohydrin was added to the reaction mixture and further heating at $80^{\circ} \mathrm{C}$ lasted for another 3 hours. The resulting mixture is alternately washed with $1 \%$ sodium carbonate solution and water. Filtration is performed after drying at $90^{\circ} \mathrm{C}$ and $130 \mathrm{~mm} \mathrm{Hg}$. The outcome of phosphate of oxypropylated phenol is $485.0 \mathrm{~g}$ $(97 \%)$, acid number is $0.07 \mathrm{mg} \mathrm{KOH} / \mathrm{g}$, ester number is $336 \mathrm{mg} \mathrm{KOH} / \mathrm{g}$, m. w. 500.

In order to study the obtained plasticizers for flammability, their mixtures were composed on the basis of the obtained esters of adipic acid with the addition of various amounts of phosphate of oxypropylated phenol.

\section{Table 1}

Physical and chemical properties of adipic acid esters $\left(\mathrm{ROCO}\left(\mathrm{CH}_{2}\right)_{4} \mathrm{COOR}^{1}\right)$

\begin{tabular}{|c|c|c|c|c|c|c|c|c|}
\hline $\begin{array}{c}\text { № } \\
\text { ester }\end{array}$ & $\mathbf{R}$ & $\mathbf{R}^{1}$ & $\begin{array}{c}\text { Boiling point } \\
\text { at } 12 \mathrm{~mm} \mathrm{Hg} \text {, } \\
{ }^{\circ} \mathrm{C}\end{array}$ & $\begin{array}{c}\text { Acid } \\
\text { number, } \\
\mathrm{mg} \mathrm{KOH} / \mathrm{g}\end{array}$ & $\begin{array}{c}\text { Ester } \\
\text { number, } \\
\text { mg KOH/g }\end{array}$ & $\mathrm{d}^{20}{ }_{4}$ & $\mathrm{n}^{20}{ }_{\mathrm{D}}$ & $\begin{array}{c}\text { Pour } \\
\text { point, }{ }^{\circ} \mathrm{C}\end{array}$ \\
\hline 1 & $n-\mathrm{C}_{6} \mathrm{H}_{13}$ & $\begin{array}{c}\text { Cyclo- } \\
\mathrm{C}_{6} \mathrm{H}_{11} \mathrm{CH}_{2}\end{array}$ & $210-235$ & 0.08 & 344 & 1.4592 & 0.9734 & -47 \\
\hline 2 & $\begin{array}{c}\text { Cyclo- } \\
\mathrm{C}_{6} \mathrm{H}_{11} \mathrm{CH}_{2}\end{array}$ & $\begin{array}{c}\text { Cyclo- } \\
\mathrm{C}_{6} \mathrm{H}_{11} \mathrm{CH}_{2}\end{array}$ & $257-260$ & 0.08 & 328 & 1.4759 & 1.0202 & +1 \\
\hline 3 & 2-ethylhexyl & $\begin{array}{c}\text { Cyclo- } \\
\mathrm{C}_{6} \mathrm{H}_{11} \mathrm{CH}_{2}\end{array}$ & $245-255$ & 0.08 & 310 & 1.4586 & 0.9568 & -60 \\
\hline
\end{tabular}


Table 2

Indicators of flammability for mixtures of plasticizers (sec)

\begin{tabular}{|c|c|c|c|c|}
\hline \multirow{2}{*}{ № ester } & \multicolumn{4}{|c|}{ Phosphate of oxypropylated phenol, \% weight. } \\
\cline { 2 - 5 } & $\mathbf{0}$ & $\mathbf{2}$ & $\mathbf{4}$ & $\mathbf{6}$ \\
\hline 1 & 28.7 & 28.2 & 25.5 & 26.1 \\
\hline 2 & 29.0 & 28.7 & 26.5 & 27.0 \\
\hline 3 & 28.0 & 27.7 & 25.0 & 25.9 \\
\hline
\end{tabular}

\section{Discussion of results}

To determine the effectiveness of the developed mixtures of plasticizers, the change in the combustibility of PVC-plastic cable samples from the amount of phosphate of oxypropylated phenol was studied.

Tests of plasticizers in the formulation of cable plasticate brand $O-40$ composition $O M-40$

To obtain cable plastics, a suspension for mixing plasticizers and stabilizers was initially prepared at speed of $8000 \mathrm{rpm}$. Further, PVC composition was prepared in a rotary mixer at $120^{\circ} \mathrm{C}$ and $70 \mathrm{rpm}$ for 30 minutes. Samples of plastic were expanded at $145-150^{\circ} \mathrm{C}$ for $7-10 \mathrm{~min}$.

Tests of finished samples of cable plastics were carried out in accordance with state standard 5960-72 with changes 3-9 «PVC Elastron for isolation and protective environments of wires and cables». The test results are shown in table 2.

The results show that the flammability of the samples depends on the structure of the alcohol radical in the adipate molecule and on the content of phosphates in the mixture of plasticizers.

The results given in table 2 show that the samples of asymmetric ester of adipic acid with a content of $4 \%$ by weight of phosphate oxypropylated phenol in terms of flammability provide lower values than commercially available (according to state standard 5960-72 with changes 3-9 for cable plastic compound of the O-40 brand the norm makes no more than $30 \mathrm{sec}$ ). An increase in the amount of phosphate of oxypropylated phenol leads to a deterioration in the flammability of plastics obtained with this mixture of plasticizers. Namely small quantities of additives to achieve optimal results - maintaining good compatibility adipate with PVC and improved physico-mechanical properties of PVC compounds based on them, as well as giving a new quality, reducing flammability.

\section{SUMMARY}

Thus, the studies show:

- asymmetric esters of adipic acid and aliphatic alcohols, which are composed of one cycloalkyl radical, characterized by the best solidification temperature;

- samples of PVC compositions based on mixed plasticizers containing asymmetric esters of adipic acid and phosphate of oxypropylated phenol have a low flammability value;

- for maximum reduction values of flammability it is necessary to use small quantities of phenoxypropylated phosphate (less than $4 \%$ ). 


\section{ВВЕДЕНИЕ}

$\Pi$ оливинилхлорид содержит до 56\% хлора, поэтому в чистом виде не горюч. Однако при добавлении пластификаторов горючесть материалов на его основе увеличивается, резкое изменение наблюдается при содержании добавок более чем $25 \%$ [1-6].

Из литературных данных известно, что низкие показатели горючести полимерным материалам придают фосфорсодержащие соединения [7-13]. Наиболее эффективными антипиренами являются триарилфосфаты. Однако фосфорсодержащие пластификаторы не находят широкого применения, так как негативно влияют на ряд физико-механических свойств композиций: низкотемпературную гибкость, летучесть, термическую стабильность и цветостабильность; также их применение усложняет технологию переработки полимерных материалов [14-17].

Этими недостатками не обладают сложные эфиры адипиновой кислоты, которые к тому же ещё придают ПВХ-материалам стабильность при низких температурах, устойчивость под действием УФ света, высокую устойчивость к миграции в бензин и масла [18-22].

Поэтому нами были исследованы смешанные пластификаторы на основе эфиров адипиновой кислоты с добавлением небольших количеств арилсодержащих фосфатов.

\section{ОСНОВНАЯ ЧАСТЬ}

\section{Экспериментальная часть}

Нами были проведены исследования по получению смеси адипинатов алифатических спиртов и малых количеств феноксипропилированного фос- фата, обладающей низкими значениями горючести ПВХ-пластикатов.

В данной работе приводятся методы синтеза, физико-химические свойства симметричных и несимметричных адипинатов алифатических спиртов и феноксипропилированного фосфата, результаты их испытаний в качестве кабельных композиций.

\section{Методика получения симметричных адипинатов} циклических алифатических спиртов

Получение симметричных адипинатов осуществляют в присутствии концентрированной серной кислоты (катализатор) в растворе азетропного водовыносителя толуола, при кипении последнего. Мольное соотношение взятых для реакции спиртов и адипиновой кислоты составляет 2,2:1. Протекание реакции контролируют по количеству выделившейся воды и кислотному числу этерификата. После охлаждения реакционную массу промывают последовательно от катализатора 5\%-ным раствором щелочи и водой до нейтральной реакции. Полученные сложные эфиры сушат над свежепрокаленным сульфатом натрия и отгоняют растворитель под вакуумом. Выход целевых продуктов составляет 96-98\%.

Методика получения несимметричных адипинатов циклических и ациклических алифатических спиртов

Несимметричные эфиры адипиновой кислоты получают в две стадии. На первой стадии в условиях, описанных выше при мольном соотношении кислота : спирт = 1:1, синтезируют моноэфиры ациклических спиртов. Далее их выделяют с помощью 10\%-ного раствора гидроксида натрия с последующей обработкой соляной кислотой. На второй стадии полученные моноэфиры в тех же условиях этерифицируют циклогексилкарбинолом при мольном соотношении кислота : спирт $=1: 1,2$. Выход несимметричных эфиров не менее $96 \%$.

\section{Таблица 1}

Физико-химические свойства эфиров адипиновой кислоты $\left(\mathrm{ROCO}\left(\mathrm{CH}_{2}\right)_{4} \mathrm{COOR}^{1}\right)$

\begin{tabular}{|c|c|c|c|c|c|c|c|c|}
\hline $\begin{array}{l}\text { № } \\
\text { эфи- } \\
\text { pa }\end{array}$ & $\mathbf{R}$ & $\mathbf{R}^{1}$ & $\begin{array}{c}\text { Tемпература } \\
\text { кипения при } \\
12 \text { мм.рт.ст., } \\
{ }^{\circ} \mathrm{C}\end{array}$ & $\begin{array}{l}\text { К.ч., мг } \\
\text { КОН/г }\end{array}$ & $\begin{array}{l}\text { Э.ч., мг } \\
\text { КОН/г }\end{array}$ & $\mathrm{d}^{20}{ }_{4}$ & $\mathrm{n}^{20}{ }_{\mathrm{D}}$ & $\begin{array}{c}\text { Темпера- } \\
\text { тура за- } \\
\text { стывания, } \\
{ }^{\circ} \mathrm{C}\end{array}$ \\
\hline 1 & $H-\mathrm{C}_{6} \mathrm{H}_{13}$ & $\begin{array}{c}\text { Цикло- } \\
\mathrm{C}_{6} \mathrm{H}_{11} \mathrm{CH}_{2}\end{array}$ & $210-235$ & 008 & 344 & 1,4592 & 0,9734 & -47 \\
\hline 2 & $\begin{array}{c}\text { Цикло- } \\
\mathrm{C}_{6} \mathrm{H}_{11} \mathrm{CH}_{2}\end{array}$ & $\begin{array}{c}\text { Цикло- } \\
\mathrm{C}_{6} \mathrm{H}_{11} \mathrm{CH}_{2}\end{array}$ & $257-260$ & 0,08 & 328 & 1,4759 & 1,0202 & +1 \\
\hline 3 & 2-этилгексил & $\begin{array}{c}\text { Цикло- } \\
\mathrm{C}_{6} \mathrm{H}_{11} \mathrm{CH}_{2}\end{array}$ & $245-255$ & 0,08 & 310 & 1,4586 & 0,9568 & -60 \\
\hline
\end{tabular}


Физико-химические показатели синтезированных эфиров адипиновой кислоты приведены в табл. 1.

Из табл. видно, что структура спиртовых радикалов в полученных эфирах существенным образом влияет на низкотемпературные свойства сложных эфиров. Замена двух ациклических алкильных радикалов на циклические структуры приводит, вероятно, к получению более жестких и менее гибких молекул. Замена алкильных групп нормального строения на разветвленные позволяет получить эфиры адипиновой кислоты с температурой застывания ниже $-60^{\circ} \mathrm{C}$.

Фосфат оксипропилированного фенола получали в два этапа. В первую очередь синтезировали оксипропилированный фенол. Затем этерификацией его с адипиновой кислотой получали конечный продукт.

\section{Методика оксипропилирования фенола}

В реактор, снабженный мешалкой, холодильником, термометром, опущенным в жидкость, и капельной воронкой загружают 94,0 г (1 моль) фенола и катализатор гидроксид натрия в количестве 1,6 г (1,0\% масс. от общей загрузки). Включают перемешивание и обогрев колбы, продувают азотом для удаления воздуха. По достижении заданной температуры из капельной воронки постепенно вводят 58,0 г (1 моль) оксида пропилена. После прекращения подачи реакционную смесь перемешивают в течение 1,5 часа без изменения температуры, затем охлаждают. Для удаления катализатора смесь нейтрализуют расчетным количеством серной кислоты и фильтруют. После осушения безводным сульфатом натрия перегоняют под вакуумом. Выход 1-фенокси2 -пропанола 147,1 г (96,8\%), $\mathrm{d}^{20}{ }_{4}=1,063$ г/мл, $\mathrm{n}^{20}{ }_{\mathrm{D}}=$ 1,525 , мол. масса 152 , степень оксипропилирования -1 .

\section{Методика этерификации фосфорной кислоты}

К смеси 153,3 г (1,0 моль) оксихлорида фосфора и 1,0 г (0,01 моль) безводного хлорида магния, нагретой до $45^{\circ} \mathrm{C}$, добавляют в течение трех часов 456 г
(3,1 моль) 1-фенокси-2-пропанола. Реакционную смесь перемешивают и нагревают до $80^{\circ} \mathrm{C} / 30$ мм рт. ст. в течение восьми часов. К реакционной смеси добавляют 25 г (0,27 моль) эпихлоргидрина и продолжают нагрев при температуре $80^{\circ} \mathrm{C}$ еще 3 часа. Полученную смесь поочередно промывают $1 \%$ раствором карбоната натрия и водой. После осушения при $90^{\circ} \mathrm{C}$ и 130 мм рт. ст. фильтруют. Выход фосфата оксипропилированного фенола - 485,0 г (97\%), кислотное число - 0,07 мг КОН/г, эфирное число 336 мг КОН/г, мол. масса - 500.

С целью исследования полученных пластификаторов на горючесть были составлены их смеси на основе полученных эфиров адипиновой кислоты с добавлением различных количеств фосфата оксипропилированного фенола.

\section{Обсуждение результатов}

Для определения эффективности разработанных смесей пластификаторов было исследовано изменение показателей горючести образцов кабельных ПВХ-пластикатов от количества фосфата оксипропилированного фенола.

Испытания пластификаторов в рецептуре кабельного пластиката марки O-40 реи. ОМ-40

Для получения кабельных пластикатов первоначально при скорости мешалки 8000 об/мин готовили суспензию для смешивания пластификаторов и стабилизаторов. Далее в роторном смесителе при $120^{\circ} \mathrm{C}$ и 70 об/мин в течение 30 мин готовили ПВХкомпозицию. Полученные образцы пластиката вальцевали при $145-150^{\circ} \mathrm{C}$ в течение 7-10 мин.

Испытания готовых образцов кабельных пластикатов проводили по ГОСТ 5960-72 с изм. 3-9 «Пластикат поливинилхлоридный для изоляции и защитных оболочек проводов и кабелей». Результаты испытаний приведены в табл. 2.

Из полученных результатов видно, что горючесть исследованных образцов зависит как от строения

Таблица 2

Показатели горючести смесей пластификаторов (c)

\begin{tabular}{|c|c|c|c|c|}
\hline \multirow{2}{*}{ № эфира } & \multicolumn{4}{|c|}{ Фосфат оксипропилированного фенола, \% масс. } \\
\cline { 2 - 5 } & $\mathbf{0}$ & $\mathbf{2}$ & $\mathbf{4}$ & $\mathbf{6}$ \\
\hline 1 & 28,7 & 28,2 & 25,5 & 26,1 \\
\hline 2 & 29,0 & 28,7 & 26,5 & 27,0 \\
\hline 3 & 28,0 & 27,7 & 25,0 & 25,9 \\
\hline
\end{tabular}


спиртового радикала в молекуле адипинатов, так и от содержания фосфатов в смеси пластификаторов.

Приведенные в табл. 2 результаты показывают, что образцы несимметричного эфира адипиновой кислоты с содержанием 4\% масс. фосфата оксипропилированного фенола по показателям горючести обеспечивают более низкие значения, чем серийно выпускаемые (норма по ГОСТ 5960-72 с изм. 3-9 для кабельного пластиката марки О-40 составляет не более 30 с). Увеличение количества фосфата оксипропилированного фенола приводит к ухудшению показателей горючести пластикатов, полученных с данной смесью пластификаторов. Именно малые количества добавки позволяют достичь оптимального результата - сохранение хорошей совместимости адипинатов с ПВХ и улучшенных физико-механических свойств пластикатов на их основе, а также придание нового качества, снижение горючести.

\section{ВЫВОДЫ}

Таким образом, проведенные исследования показывают:

- несимметричные эфиры адипиновой кислоты и алифатических спиртов, имеющие в составе один циклоалкильный радикал, характеризуются наилучшими показателями температуры застывания;

- образцы ПВХ-композиций на основе смешанных пластификаторов, содержащих несимметричные эфиры адипиновой кислоты и фосфата оксипропилированного фенола обладают низким значением горючести;

- для максимального снижения значений горючести необходимо использование малых количеств феноксипропилированного фосфата (менее 4\%).

\section{REFERENCES}

1. Fedorenko N.P., Universalnyi plastik (Polivinilkhlorid) [Universal plastic (Polyvinylchloride)]. Moscow. Science, 1966. 119 p. (In Russian).

2. Maskova A.R., Aminova G.K., Rolnik L.Z., Faizullina G.F., Mazitova A.K. Oxyalkylated alcohols phthalates. Nanotehnologii $\mathrm{v}$ stroitel'stve $=$ Nanotechnologies in Construction. 2019, Vol. 11, no. 1, pp. 52-71. DOI: 10.15828/2075-8545-2019-11-1-52-71.

3. Mazitova A.K., Aminova G.K., Maskova A.R., Sabitov I.N., Nedoseko I.V. New polyvinylchloride plasticizers. Nanotehnologii $\mathrm{v}$ stroitel'stve $=$ Nanotechnologies in Construction. 2017, Vol. 9, no. 6, pp. 168-180. DOI: 10.15828/2075-8545-2017-9-6-168-180.

4. Mazitova A.K., Aminova G.K., Maskova A.R., Yagafarova G.G., Mazitov R.M. New plasticizers for PVC-compositionsin construction. Nanotehnologii v stroitel'stve = Nanotechnologies in Construction. 2017, Vol. 9, no. 4, pp. 48-63. DOI: 10.15828/20758545-2017-9-4-48-63.

5. Mazitova A.K., Stepanova L.B., Aminova G.F., Maskova A.R. Razrabotka funkcional'nyh dobavok dlja polivinilhloridnyhkompozicij stroitel'nogo naznachenija [Development of functional additives for polyvinylchloride compositions for construction purposes]. Promyshlennoe proizvodstvo i ispol'zovaniejelastomerov [Industrial production and use of elastomers]. 2015. no. 2, pp. 27-31. (In Russian).

6. Mazitova A.K., Aminova G.K., Nafikova R.F., Deberdeev R.Ja. Osnovnye polivinilhloridnye kompozicii stroitel'nogo naznachenija [Main polyvinylchloride compositions for building purposes]. Ufa, 2013. 130 p. (In Russian).

7. Sapaev H.H., Musov I. V., Hashirova S. Yu., Bashorov M. T., Shogenov V.N., Kushkhov H.B., Mikitaev A.K., Zaikov G.E. Izuchenie vliyaniya razlichnyh plastifikatorov na svojstva polivinilhloridnogo plastikata [Study of the influence of various plasticizers on the properties of polyvinylchloride plasticate]. Vestnik tekhnologicheskogo universiteta [Bulletin of Technological University]. 2015. Tom 18, № 9, pp. 102-105. (In Russian).

8. Khalturinsky N.A., Berlin A.A., Popova T.V. Gorenie polimerov i mekhanizmy dejstviya antipirenov [The burning of polymers and the mechanisms of action of flame retardant substances]. Uspekhi khimii [Chemical success]. 1984. Vol. 53, № 2, pp. 326. (In Russian).

9. Moisa Iu. N. Plast. massy [Plastic]. 1978. no. 9, pp. 33-35. (In Russian).

10. Ottmar L. Kunststoffe. 1971, Bd. 61, no. 1, pp. 40-46.

11. Tashiro M. Polymer Appl. 1971, Vol. 20, no. 5, pp. 273-278.

12. Troitskii I.D. Polivinilkhloridnye plastikaty i ikh primenenie v kabelnoi tekhnike i ikh primenenie v kabelnoi tekhnike [Polyvinylchloride plasticates and their application in cable engineering and their application in cable engineering]. Moscow. Energy, 1978. 152 p. (In Russian).

13. Musov I.V., Vindizheva A.S., Sapaev H.H., Hashirova S.Yu., Ligidov M.H., Mikitaev A.K. Razrabotka ognestojkogo polivinilhloridnogo plastikata [Development of fire-resistant polyvinylchloride plasticate]. Plasticheskie massy [Plastic masses]. 2011. № 10, pp. 34-36. (In Russian).

14. Musov I.V., Vindizheva A.S., Hashirova S.Yu., Sapaev H.H., Mikitaev A.K. Polivinilhloridnyj plastikat s povyshennoj ognestojkost'yu [Polyvinylchloride plasticate with high fire resistance]. Naukoemkie tekhnologii [High technology]. 2012. № 1, pp. 27-30. (In Russian). 
15. Berlin A.A., Vol'fson S.A., Oshmyan V.G., Enikolopyan N.S. Principy sozdaniya kompozicionnyh materialov [Principles of creation of composite materials]. Moscow. Chemistry, 1990. 240 p. (In Russian).

16. Mazitova A.K., Maskova A.R., Nafikova R.F., Aminova G.K. Ispol'zovanie dobavok pri poluchenii kabel'nyh plastikatov [The use of additives in the production of cable plastics]. Bashkirskij himicheskij zhurnal [Bashkir chemical journal]. 2017. Tom 24, № 3, pp. 50-53. (In Russian).

17. Rukovodstvo po razrabotke kompozicij na osnove PVH [Guidelines for the development of compositions based on PVC] / Pod red. Grossmana R.F. [Under the General editorship of R.F. Grossmana]. Saint-Petersburg. Scientific basis and technologies, 2009. 608 p. (In Russian).

18. Sheryshev M.A., Tihonov N.N. Proizvodstvo profil'nyh izdelij iz PVH [Production of profile products from PVC]. SaintPetersburg. Scientific basis and technologies, 2012. 614 p. (In Russian).

19. Mazitova A.K., Nafikova R.F., Aminova G.K. Plastifikatory polivinilhlorida [Plasticizers of polyvinylchloride]. Nauka i jepoha: monografija. Pod obshhej redakciej professora O.I. Kirikova [Science and epoch: monograph. Under the General editorship of Professor O. I. Kirikova]. Moscow; Voronezh, 2011. pp. 277-297. (In Russian).

20. Uilki Ch., Sammers J., Daniels Ch. Polivinilhlorid [Polyvinylchloride]. Saint-Petersburg. Profession, 2007. 728 p. (In Russian).

21. Barshteyn R.S., Kirilovich V.I., Nosovskiy Y.E. Plastifikatory dlja polimerov [Plasticizers for polymers]. Moscow. Chemistry, 1982. 196 p. (In Russian).

22. Tinius K. Plastifikatory [Plasticizers]. Moscow. Chemistry, 1964. 915 p. (In Russian).

\section{СПИСОК ЛИТЕРАТУРЫ}

1. Федоренко Н.П. Универсальный пластик (Поливинилхлорид). - М.: Наука, 1966. - 119 с.

2. Маскова А.Р., Аминова Г.К., Рольник Л.З., Файзуллина Г.Ф., Мазитова А.К. Фталаты оксиалкилированных спиртов // Нанотехнологии в строительстве. - 2019. - Том 11, № 1. - C. 52-71. - DOI: 10.15828/2075-8545-2019-11-1-52-71.

3. Мазитова А.К., Аминова Г.К., Маскова А.Р., Сабитов И.Н., Недосеко И.В. Новые пластификаторы поливинилхлорида // Нанотехнологии в строительстве. - 2017. - Том 9, № 6. - С. 168-180. - DOI: 10.15828/20758545-2017-9-6-168-180.

4. Мазитова А.К., Аминова Г.К., Маскова А.Р., Ягафарова Г. Г., Мазитов Р.М. Новые пластификаторы для ПВХкомпозиций строительного назначения // Нанотехнологии в строительстве. - 2017. - Том 9, № 4. - C. 48-63. - DOI: 10.15828/2075-8545-2017-9-4-48-63.

5. Мазитова А.К., Степанова Л.Б., Аминова Г.Ф., Маскова А.Р. Разработка функциональных добавок для поливинилхлоридных композиций строительного назначения // Промышленное производство и использование эластомеров. 2015. - № 2. - C. 27-31.

6. Мазитова А.К., Аминова Г.К., Нафикова Р.Ф., Дебердеев Р.Я. Основные поливинилхлоридные композиции строительного назначения. - Уфа, 2013. - 130 с.

7. Сапаев Х.Х., Мусов И.В., Хаширова С.Ю., Башоров М.Т., Шогенов В.Н., Кушхов Х.Б., Микитаев А.К., Заиков Г.Е. Изучение влияния различных пластификаторов на свойства поливинилхлоридного пластиката // Вестник технологического университета. - 2015. - Том 18, № 9. - С. 102-105.

8. Халтуринский Н.А., Берлин А.А., Попова Т.В. Горение полимеров и механизмы действия антипиренов // Успехи химии. - 1984. - Т. 53, № 2. - С. 326.

9. Мойса Ю.Н. и др. // Пласт. массы. - 1978. - № 9. - С. 33-35.

10. Ottmar L. // Kunststoffe. - 1971. - Bd. 61, № 1. - P. 40-46.

11. Tashiro M. // Polymer Appl. - 1971. - Vol. 20, № 5. - Р. 273-278.

12. Троицкий И.Д. Поливинилхлоридные пластикаты и их применение в кабельной технике и их применение в кабельной технике. - М.: Энергия, 1978. - 152 с.

13. Мусов И.В., Виндижева А.С., Сапаев Х.Х., Хаширова С.Ю., Лигидов М.Х., Микитаев А.К. Разработка огнестойкого поливинилхлоридного пластиката // Пластические массы. - 2011. - № 10. - С. 34-36.

14. Мусов И.В., Виндижева А.С., Хаширова С.Ю., Сапаев Х.Х., Микитаев А.К Поливинилхлоридный пластикат с повышенной огнестойкостью // Наукоемкие технологии. - 2012. - № 1. - С. 27-30.

15. Берлин А.А., Вольфсон С.А., Ошмян В.Г., Ениколопян Н.С. Принципы создания композиционных материалов. - М.: Химия, 1990. - 240 с.

16. Мазитова А.К., Маскова А.Р., Нафикова Р.Ф., Аминова Г.К. Использование добавок при получении кабельных пластикатов // Башкирский химический журнал. - 2017. - Том 24, № 3. - С. 50-53.

17. Руководство по разработке композиций на основе ПВХ / Под ред. Гроссмана Р.Ф. Пер. с англ. под ред. Гузеева В.В. - СПб.: Научные основы и технологии, 2009. - 608 с.

18. Шерышев М.А., Тихонов Н.Н. Производство профильных изделий из ПВХ. - СПб.: Научные основы и технологии, 2012. - $614 \mathrm{c}$.

19. Мазитова А.К., Нафикова Р.Ф., Аминова Г.К. Пластификаторы поливинилхлорида / Наука и эпоха: монография; под общей ред. проф. О.И. Кирикова. - Воронеж, 2011. - С. 277-297.

20. Уилки Ч., Саммерс Дж., Даниелс Ч. Поливинилхлорид. - СПб.: Профессия, 2007. - 728 с.

21. Барштейн Р.С, Кирилович В.И., Носовский Ю.Е. Пластификаторы для полимеров. - М.: Химия, $1982 .-196$ с.

22. Тиниус К. Пластификаторы. - М.: Химия, 1964. - 915 с. 


\section{INFORMATION ABOUT THE AUTHORS}

Aliya K. Mazitova, Doctor of Chemistry, Professor, Head of Applied and Natural Sciences Department, Ufa State Petroleum Technological University; Mendeleev St., 195, Ufa, Bashkortostan Republic, Russia, 450080; elenaasf@yandex.ru;

Irina N. Vikhareva, Assistant, Applied and Natural Sciences Department, Ufa State Petroleum Technological University; Mendeleev St., 195, Ufa, Bashkortostan Republic, Russia, 450080; vikhir@yandex.ru;

Guliya K. Aminova, Doctor of Engineering, Professor, Applied and Natural Sciences Department, Ufa State Petroleum Technological University; Mendeleev St., 195, Ufa, Bashkortostan Republic, Russia, 450080; aminovagk@inbox.ru;

Andrey A. Timofeev, Associate Professor, Applied and Natural Sciences Department, Ufa State Petroleum Technological University; Mendeleev St., 195, Ufa, Bashkortostan Republic, Russia, 450080; tiandre@mail.ru;

Evgeniya A. Buylova, PhD in Chemistry, Associate Professor, Applied and Natural Sciences Department, Ufa State Petroleum Technological University; Mendeleev St., 195, Ufa, Bashkortostan Republic, Russia, 450080; asunasf@mail.ru;

Ramil Sh. Distanov, PhD in Engineering, Senior lecturer, Applied and Natural Sciences Department, Ufa State Petroleum Technological University; Mendeleev St., 195, Ufa, Bashkortostan Republic, Russia, 450080; distanov_ramil1@mail.ru

\section{ИНФОРМАЦИЯ ОБ АВТОРАХ}

Мазитова Алия Карамовна, д.Х.н., проф., зав. каф. «Прикладные и естественнонаучные дисциплины», ФГБОУ ВО «Уфимский государственный нефтяной технический университет»; ул. Менделеева, 195, г. Уфа, Республика Башкортостан, Россия, 450080; elenaasf@yandex.ru;

Вихарева Ирина Николаевна, ассистент каф. «Прикладные и естественнонаучные дисциплины», ФГБОУ ВО «Уфимский государственный нефтяной технический университет»; ул. Менделеева, 195, г. Уфа, Республика Башкортостан, Россия, 450080; vikhir@yandex.ru;

Аминова Гулия Карамовна, д.т.н., проф. каф. «Прикладные и естественнонаучные дисциплины», ФГБОУ ВО «Уфимский государственный нефтяной технический университет»; ул. Менделеева, 195, г. Уфа, Республика Башкортостан, Россия, 450080; aminovagk@inbox.ru;

тимофеев Андрей Алексеевич, доцент каф. «Прикладные и естественнонаучные дисциплины», ФГБОУ ВО «Уфимский государственный нефтяной технический университет»; ул. Менделеева, 195, г. Уфа, Республика Башкортостан, Россия, 450080; tiandre@mail.ru;

Буйлова Евгения Андреевна, к.Х.н., доцент каф. «Прикладные и естественнонаучные дисциплины», ФГБОУ ВО «Уфимский государственный нефтяной технический университет»; ул. Менделеева, 195, г. Уфа, Республика Башкортостан, Россия, 450080; evg-builova@yandex.ru;

Дистанов Рамиль Шамильевич, к.т.н., старший преподаватель кафедры «Прикладные и естественнонаучные дисциплины», ФГБОУ ВО «Уфимский государственный нефтяной технический университет»; ул. Менделеева, 195, г. Уфа, Республика Башкортостан, 450080; distanov_ramil1@mail.ru 